\title{
An Indonesian Adaptation of the World Health Organization Adverse Childhood Experiences International Questionnaire (WHO ACE-IQ) as a Screening Instrument for Adults
}

\author{
Satwika Rahapsari ${ }^{1}$, Valendra Granitha Shandika Puri ${ }^{2}$, Adelia Khrisna Putri ${ }^{3}$ \\ 1,2,3Faculty of Psychology, Universitas Gadjah Mada
}

\begin{abstract}
There has been little research in Indonesia about Adverse Childhood Experiences (ACE). Whereas, research on this topic is urgently needed as the baseline for a national evidence-based child protection policy. Even though the worldwide prevalence of ACE is high, there is no comprehensive study in the Indonesian context in regards to ACE identification and the impact on the survivors' mental and physical health. Therefore, an ACE screening instrument is urgently needed as the first step for conducting research on this topic. This research aims to examine the validity and reliability of the WHO ACE-IQ or the World Health Organization Adverse Childhood Experience International Questionnaire as an ACE screening instrument in Indonesia. The researcher conducted a cross-sectional survey in 240 participants aged 18-65 years old using an online self-administered questionnaire. The outcome of this research is the Indonesian adapted WHO ACE-IQ is able to provide a reliable, accurate, and valid score of $\mathrm{ACE}$ in the Indonesian adult population
\end{abstract}

Keywords: adverse childhood experiences; Indonesia; validity; WHO ACE-IQ

Adverse Childhood Experiences (ACE) refers to experiences that are the source of acute stress and trauma experienced by individuals during childhood, who are under 18 years old. These experiences include psychological abuse, physical abuse, sexual abuse, neglect, violence between parents or caregivers, as well as various kinds of dysfunction in the family e.g., drug abuse and alcohol addiction, violence by peers, violence in the community e.g., gang activity, and collective violence e.g., inter-ethnic conflict or war (World Health Organization, 2018).

Unfortunately, information about violence experienced by children is difficult to find. Children usually cannot talk freely about the violence they experience on daily basis; such as bullying, neglect by parents, or sexual harassment; even after being asked by their teacher or health workers. Child victims of violence often display silent behavior, always wary, or aggressive. If they consulted with a psychologist or medical personnel, they will get a diagnosis such as oppositional disorder or emotional regulation disorder (Van der Kolk, 2015). Without knowing the root of this psychological problem, they will receive the "problem child" label as they grow older. This also influences the inaccuracy of intervention that often leads to bigger problems (Van der Kolk, 2015); even though the 
problematic behavior appears as a psychological response to the impact of exposure to violence. The phenomenon was explained by Gee and Casey (2015); during their developmental period, children and adolescents experience a sensitive period of brain development which means that exposure to stress and trauma will increase susceptibility to the adverse effects of stress and trauma.

A study about ACE on a large scale was first conducted by Kaiser Permanente's Department of Preventive Medicine in San Diego, in collaboration with the US Centers for Disease Control and Prevention (CDC), United States of America. The results of the study were quite surprising, adverse childhood experiences turned out to have a large impact on mental condition, health risks, disease, sexual behavior, disabilities, and health cost for survivors in the next ten years (Dube et al., 2005; Felitti et al., 1998). ACE is consistently associated with mental disorders in an individual during childhood, as well as in the later stages of development, namely adolescence and adulthood. This is due to adverse experiences that cause acute stress in early childhood and interfere with children's brain development. They also affect the nervous system and immune system until adulthood. In addition, through imitation of negative behavior by an individual who was exposed to violence from the family can also lead to alcohol addiction, depression, eating disorders, unhealthy sexual behavior, HIV/AIDS, heart disease, cancer, and other chronic diseases (Dube et al., 2003). Other studies showed the impact of adverse childhood experiences on the spread of biomedical diseases such as liver disease, chronic respiratory problems, coronary heart disease, and autoimmune diseases (Hughes et al., 2016). Norman et al. (2012) revealed other impacts of ACE, including risky behavior such as smoking, drug use, obesity, and premature sexual activity. Furthermore, adverse childhood experiences are also associated with reduced life expectancy in survivors (Felitti et al., 1998). The more exposure to violence experienced by children, the greater the risk of physical and mental health problems (Mersky et al., 2013).

In developing countries like Indonesia, where the average income is classified as low to medium; poverty and inequality are ongoing problems and have a negative impact on child welfare (Hasan et al., 2013). Several factors such as economic hardship, unhealthy environment, stress, violence in parenting, nonexistence government policy on mental health, et cetera can be risk factors for traumatic experiences during child development.

Studies on ACE have also been carried out in several developing countries. A study by Thang et al. (2017) on the impact of emotional, physical, and social abuse on mental health and risky behavior among students in five ASEAN countries (Indonesia, Malaysia, Myanmar, Thailand, and Vietnam) showed that violence increases the risk of mental health problems, addiction, and other risky behavior in adults. This study also showed the highest prevalence of emotional violence is in Myanmar, while the highest physical and emotional abuse is in Vietnam (Thang et al., 2017). A study on ACE in another Asian Pacific country by Lui et al. (2018) was conducted in Solomon Island. Although the 
participants of the study were only male, the results were quite surprising. $80.7 \%$ of the participants reported experiencing more than 3 types of violence and $46 \%$ reported experiencing more than 5 types in their childhood. Those violent experiences include violence in the family, bullying, neglect of primary needs, and sexual violence. Further research by Ramiro et al. (2010) revealed that $75 \%$ of participants of a study in the Philippines reported having experienced at least one type of violence during their childhood.

According to a study by United Nations (UN) about males and violence in six Asian Pacific countries including Indonesia, there was strong evidence of sexual violence experienced by men in their childhood (Fulu et al., 2013). Through random sampling of 2577 adult males aged 18-49 years old, it is known that sexual violence is a common phenomenon that occurs in these six countries. Based on the study, reports of sexual violence against individuals under 18 years old in Indonesia were $12 \%$ in Jayapura, Papua, 7\% in Jakarta, and 6\% in Purworejo (Fulu et al., 2013).

Compared to other countries, research on ACE in Indonesia is still rare even though cases of violence against children deserve serious attention. To promote programs and policies for the prevention and curation of violence against children, a database is needed from diverse and comprehensive research on ACE in Indonesia. Unfortunately, it is still not yet known certainly the prevalence of violence in childhood experienced by Indonesian. Several studies have been conducted but it is still yet known whether comprehensive results can be used as strong evidence to develop child protection policy in Indonesia. In addition, these studies used different ACE screening measures. A systematic review study by United Nations Children's Fund (Rumble et al., 2018) showed that empirical study on one of the prevalence components in ACE, namely sexual violence against children in Indonesia, along with risk and protective factors is still very rare. In fact, in 2013 the Indonesian Government conducted a national survey on violence against children involving 2580 men and women aged 13-24 years old. However, the results were not as expected, such as low response rate, inadequate data on several variables, and data anomalies (Rumble et al., 2018). Therefore, there are several inputs for further study on child abuse in Indonesia, including improving the protection of privacy and anonymity of participants and paying attention to socio-cultural context (Rumble et al., 2018). Finkelhor and Lannen (2015) stated that national surveys on violence rarely reveal neglect and sexual violence variables. Some examples of ACE study in Indonesia are studies by Pebruarini et al. (2017) which revealed the relationship between ACE and malingering behavior in prisoners; and a study by Kaloeti et al. (2019) which investigated the impact of ACE on stress, resilience, and depression symptoms in college students.

Based on the explanation above, it can be concluded that bad traumatic experiences in childhood are a phenomenon that cannot be underestimated. Unfortunately, the study on ACE in Indonesia is relatively limited and not comprehensive. Some studies only investigate certain types of violent experiences, such as sexual violence. In addition, there 
is no standard instrument that can be used to investigate ACE on a national scale. The need for standardized research instruments that cover all indicators of violence variables is also an important thing to pay attention to in research on violence. The availability of this instrument can be used as an ACE screening instrument for further studies.

One of the screening instruments used internationally is World Health Organization Adverse Childhood Experiences International Questionnaire (WHO ACE-IQ). This instrument was created by World Health Organization (World Health Organization, 2018) and has been tested on participants in Canada, Saudi Arabia, China, South Africa, Macedonia, Philippines, Switzerland, and Thailand (World Health Organization, 2018). Unfortunately, this instrument has not been adapted into the Indonesian language and culture. Therefore, this study aimed to adapt the WHO ACE-IQ instrument to the Indonesian language and cultural context, so that it can be a valid, reliable, and accurate instrument that can be used for further studies regarding violent experiences that occurred in childhood in Indonesia.

\section{Method}

\section{Design study and participants}

The design of this study is a cross-sectional survey study or data collection at one time to test the validity and reliability of the World Health Organization Adverse Childhood Experiences Internasional Questionnaire (WHO ACE-IQ) as a screening instrument for violent experience in childhood. Before conducting the data collection, this study had received approval from the Ethics Committee of Faculty of Psychology, Universitas Gadjah Mada with the number 3979/UN1/FPSi.1.3/SD/PT/2019.

Participants of this study were adults with an age range of 18-65 years old. This study used convenience sampling or depending on participant's availability; namely by distributing information broadcast on online survey link through social media platforms such as Instagram, Line, and WhatsApp. 268 participants were willing to fill out the questionnaire, but 28 participants' data could not be processed further because they were incomplete. A total of 240 participants' data could be further processed for analysis.

Data were collected through an online survey by selecting a survey platform that guarantees data encryption security (SSL/TSL Encryption) and ensures anonymity (participants' IP address was not visible). This platform also avoids repeated data filling from the same IP address. Data collection through a self-rated online survey is expected to minimize discomfort when answering sensitive questions, namely violent experiences that occurred in their childhood.

Before filling out the survey, participants were given an explanation of research procedures, rights, and obligations in the informed consent. If the participant agreed to participate in the research process, they would be asked to press the consent button in the informed consent and it was documented in the online survey form. Participants were 
also given the option to stop filling out the questionnaire in the middle of the data collection process if they felt uncomfortable and did not wish to continue.

\section{Measurement}

This study used one research instrument namely World Health Organization Adverse Childhood Experiences Internasional Questionnaire (WHO ACE-IQ) which is designed to measure ACE in adults aged 18 years old or older. This instrument was developed by WHO as an effort to standardize ACE instrument measurements that can be used around the world. This instrument had been tested on participants in Canada, Saudi Arabia, China, South Africa, Macedonia, the Philippines, Switzerland, and Thailand (World Health Organization, 2018). Through a literature study conducted by researchers, this instrument had never been adapted into the Indonesian context and there was no validation study of the Indonesian version of the WHO ACE-IQ.

The questions in this instrument measure 13 indicators; including physical abuse, emotional abuse, sexual abuse, alcohol or drugs abuse in the family, family members with depression and mental disorders, admission to the mental hospital, family members with suicidal tendencies, family members who are exposed to violence, orphan or raised by a single parent, parental separation or divorce, emotional neglect, physical neglect, bullying, and exposure to community violence and communal violence (World Health Organization, 2018).

Some of the answers in this instrument are in the form of "yes" or "no". Other answers for the questions are "often," "sometimes," "once," and "never." The scoring method is a calculation of the total experience score experienced which represents the total exposure to childhood violence when participants answered "yes," "often," "occasionally," or "once." The total ACE score is calculated based on the number of experiences the participants have had. The ACE total score is then categorized as 0, 1, 2, 3, or $>/ 4$ experiences (World Health Organization, 2018).

The original WHO ACE-IQ questionnaire is in English, so an adaptation to Indonesian is needed. Therefore, the questionnaire was translated and adapted using the adaptation process procedure by the World Health Organization. The steps for the adaptation process are as follows:

\section{Forward translation}

Two translators who understood mental health and were familiar with its terminology were asked to translate the questionnaire from English to Indonesian. Translation by two people was implemented to avoid choosing a person's language style. A translator is a person who understands the culture of speaking English but in the Indonesian native language. The translation was not carried out word for word, but involved an understanding of the concept and context of the language then translating it in a relevant way. The translation used short and clear language. It also took into account the language 
of the questionnaire users, namely lay language, to avoid the use of jargon or technical terms that are difficult to understand and not used in everyday language. In addition, translators were also required to have an IELTS English test score above 7.5 or a TOEFL IBT above 100.

\section{Content validity by Multi-SME (Subject Matter Experts)}

Content validity is carried out to measure whether the items match the measured attributes (Azwar, 2012). The content validity of the WHO ACE-IQ questionnaire was determined using the Content Validity Ratio (CVR) score by asking five Subject Matter Experts (SME) to assess whether the items of the questionnaire are following theoretical construction. CVR is calculated based on Lawshe's theory (1975) about content validity with a minimum CVR value of 0.99 as a requirement for questionnaire items to be considered essential.

\section{Back-translation}

The next step was to translate the adaptation of the WHO ACE-IQ questionnaire into English by two other translators with the conditions stated above. The purpose of backtranslation into the original language of the instrument is to ensure that there is no change in the meaning of each item when translated into another language. Details of criteria as well as questionnaire questions and answer choices in Indonesian can be seen in table 1.

Table 1.

Categories in WHO ACE-IQ Instrument

\begin{tabular}{|c|c|c|c|}
\hline No & Category & Questions (in the Indonesian Language) & $\begin{array}{l}\text { Response Options (in } \\
\text { the Indonesian } \\
\text { Language) }\end{array}$ \\
\hline \multirow[t]{2}{*}{1} & $\begin{array}{l}\text { Pengabaian emosional } \\
\text { (Emotional neglect) }\end{array}$ & $\begin{array}{l}\text { Orangtua/wali mengerti } \\
\text { permasalahan/kegelisahanmu }\end{array}$ & $\begin{array}{r}\text { Selalu } \\
\text { Hampir selalu } \\
\text { Kadang-kadang }\end{array}$ \\
\hline & & $\begin{array}{l}\text { Orang tua/wali tidak tahu aktivitasmu di waktu } \\
\text { senggang }\end{array}$ & $\begin{array}{r}\text { Jarang } \\
\text { Tidak pernah }\end{array}$ \\
\hline \multirow[t]{3}{*}{2} & $\begin{array}{l}\text { Pengabaian fisik } \\
\text { (Physical neglect) }\end{array}$ & Tidak diberi cukup makanan & $\begin{array}{r}\text { Sering } \\
\text { Kadang }\end{array}$ \\
\hline & & $\begin{array}{l}\text { Orang tua/wali/anggota keluarga terlalu mabuk } \\
\text { oleh obatan-obatan terlarang sehingga tidak } \\
\text { dapat mengurusmu }\end{array}$ & $\begin{array}{r}\text { Sekali } \\
\text { Tidak pernah }\end{array}$ \\
\hline & & Tidak bersekolah & \\
\hline 3 & $\begin{array}{l}\text { Anggota keluarga } \\
\text { pecandu alkohol atau }\end{array}$ & $\begin{array}{l}\text { Anggota keluarga alkoholik atau penyalahguna } \\
\text { obat }\end{array}$ & $\begin{array}{r}\text { Ya } \\
\text { Tidak }\end{array}$ \\
\hline
\end{tabular}


obat-obatan terlarang

(Alcohol and/or drug

abuser in the household)

\begin{tabular}{|c|c|c|c|}
\hline 4 & $\begin{array}{l}\text { Anggota keluarga } \\
\text { depresi, tendensi bunuh } \\
\text { diri, sakit mental } \\
\text { (Family member who is } \\
\text { chronically depressed, } \\
\text { mentally ill, } \\
\text { institutionalized or } \\
\text { suicidal) }\end{array}$ & $\begin{array}{l}\text { Anggota keluarga depresi, bertendensi bunuh } \\
\text { diri, atau sakit mental }\end{array}$ & $\begin{array}{r}\text { Ya } \\
\text { Tidak }\end{array}$ \\
\hline 5 & $\begin{array}{l}\text { Anggota keluarga } \\
\text { dipenjara } \\
\text { (Incarcerated family } \\
\text { member) }\end{array}$ & Anggota keluarga dipenjara & $\begin{array}{r}\text { Ya } \\
\text { Tidak }\end{array}$ \\
\hline 6 & $\begin{array}{l}\text { Salah satu atau kedua } \\
\text { orang tua meninggal, } \\
\text { orang tua berpisah atau } \\
\text { bercerai } \\
\text { (One of or both parents } \\
\text { passed away, separated, } \\
\text { or divorced) }\end{array}$ & $\begin{array}{l}\text { Orang tua berpisah/bercerai } \\
\text { Orang tua/wali telah meninggal dunia }\end{array}$ & $\begin{array}{r}\text { Ya } \\
\text { Tidak }\end{array}$ \\
\hline 7 & $\begin{array}{l}\text { Anggota keluarga } \\
\text { diperlakukan kasar } \\
\text { (Family member } \\
\text { received abuse) }\end{array}$ & $\begin{array}{l}\text { Melihat/mendengar orang tua/anggota } \\
\text { keluarga ditampar, ditendang, dipukul, atau } \\
\text { dipukuli } \\
\text { Melihat/mendengar orang tua/anggota } \\
\text { keluarga dipukul dengan objek }\end{array}$ & $\begin{array}{r}\text { Sering } \\
\text { Kadang-kadang } \\
\text { Sekali } \\
\text { Tidak pernah }\end{array}$ \\
\hline 8 & $\begin{array}{l}\text { Kekerasan } \\
\text { psikologis/emosional } \\
\text { (Psychological/emotiona } \\
1 \text { abuse) }\end{array}$ & $\begin{array}{l}\text { Orang tua/anggota keluarga mengancam untuk } \\
\text { tidak mengurusimu }\end{array}$ & $\begin{array}{r}\text { Sering } \\
\text { Kadang-kadang } \\
\text { Sekali } \\
\text { Tidak pernah }\end{array}$ \\
\hline 9 & $\begin{array}{l}\text { Kekerasan fisik } \\
\text { (physical abuse) }\end{array}$ & $\begin{array}{l}\text { Orang tua/wali/anggota keluarga memukulmu } \\
\text { dengan objek }\end{array}$ & $\begin{array}{r}\text { Sering } \\
\text { Kadang-kadang } \\
\text { Sekali } \\
\text { Tidak pernah }\end{array}$ \\
\hline
\end{tabular}




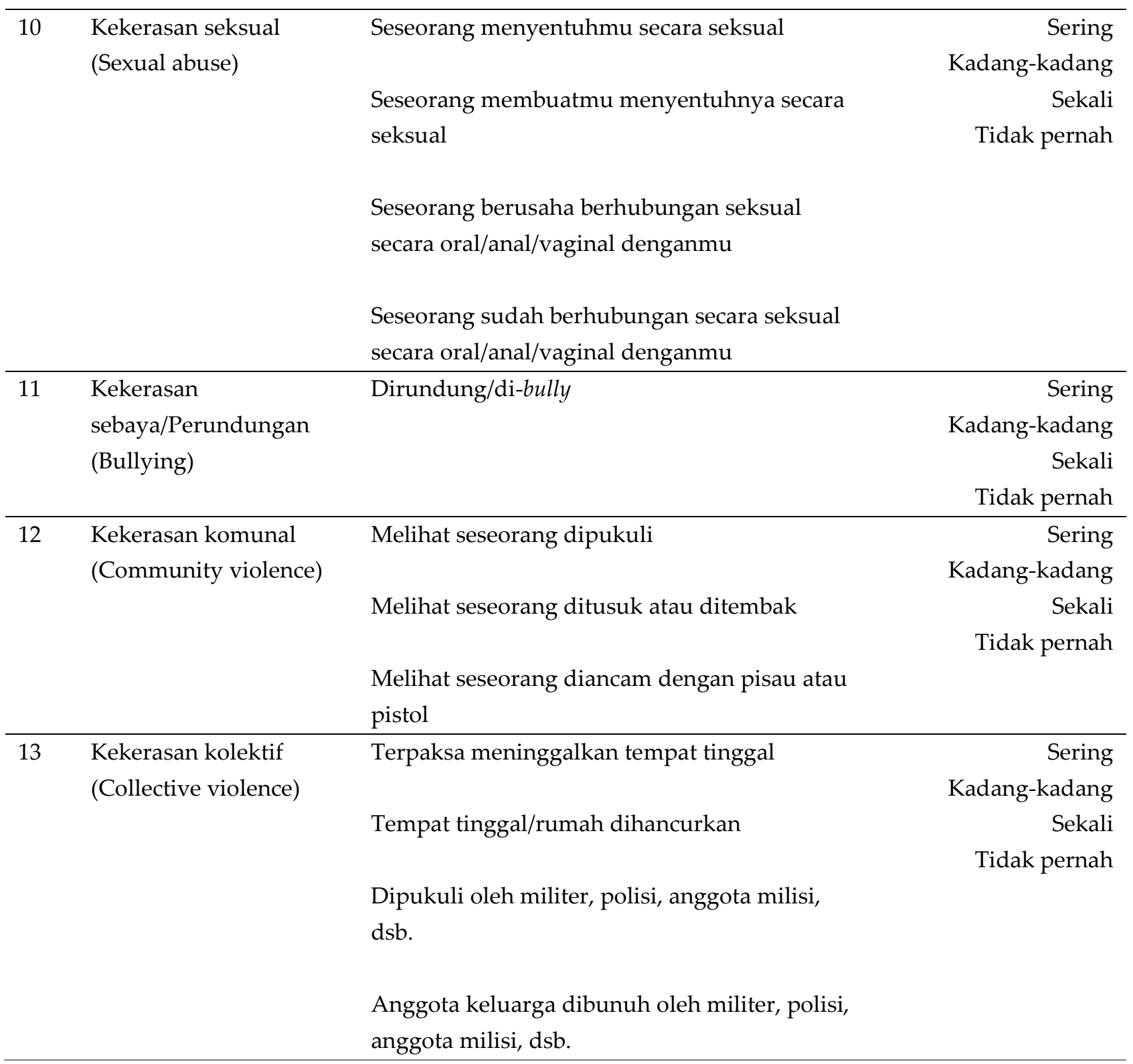

Pre-testing: Validity and reliability test

First, the instrument was tested using Cronbach's alpha reliability estimate to determine its reliability coefficient so that it can be concluded if the measurement is reliable and its results can be trusted. Then, researchers conducted psychometric identification to find out validity evidence, reliability estimation of internal consistency, and key validity criteria from the WHO ACE-IQ. The reliability estimate used in the study is internal consistency with Cronbach's alpha formula. Azwar (2012) stated that the higher the reliability coefficient, the more reliable the measurement is. This score ranges from 0.00 to 1.00. DeVaus (2004) suggested that the reliability coefficient is satisfactory if it has reached 0.70 .

The validity evidence according to validity criteria was also done in the present study. WHO ACE-IQ questionnaire would be correlated with a comparative 
measurement namely Adverse Childhood Experiences Questionnaire (ACEQ) which was developed by the Centers for Disease Control and Prevention and Kaiser Permanente in 1997. The questionnaire was adapted to the Indonesian language by Kaloeti et al. (2019). Criteria that would be compared between the two instruments encompass 10 criteria namely: physical abuse, emotional abuse, sexual abuse, alcohol and drugs abuse within the family, family members with depression and other mental health problems or being treated at mental health institution, family members with suicide tendency, witnessing family members being exposed to abuse, having no parents or only one parent, parents separation or divorce, as well as physical and emotional neglect. Three other adverse experience criteria were not correlated because they are not available in ACEQ, namely: bullying, exposure to violence within the community, and communal violence. The correlation method done was Pearson's Product Moment. Identification of criterion validity was done by comparing the correlation coefficients between the two variables.

\section{Results}

\section{Participant Characteristics}

Total data from 240 participants (75\% females) were used in the study analysis to examine the validity and reliability of WHO ACE-IQ that had been adapted to the Indonesian language. The participants' demographic distribution in the present study's sample is shown in Table 2. The average age of participants was 24 years old, and $46.9 \%$ had the educational background of bachelor-level.

Table 2.

Participants Sociodemographic Data

\begin{tabular}{lcc}
\hline \multicolumn{1}{c}{ Sociodemographic } & $\mathbf{N = 2 4 0}$ \\
\cline { 2 - 3 } & Number & Percentage (\%) \\
\hline Gender & 60 & 25 \\
Male & 180 & 75 \\
Female & & \\
Age & 151 & 62.9 \\
$18-24$ & 77 & 32.1 \\
$25-34$ & 8 & 3.3 \\
$35-44$ & 4 & 1.6 \\
$>45$ & & \\
Education & 0 & 0 \\
$<$ High School & 111 & 46.5 \\
High School & 113 & 46.9 \\
Bachelor & 16 & 6.6 \\
Master \& Doctorate & &
\end{tabular}

\section{Occupation}




\begin{tabular}{lcc} 
Civil servant & 14 & 5.8 \\
Private sector & 47 & 19.6 \\
Entrepreneur & 8 & 3.3 \\
Student & 126 & 52.5 \\
Housewife & 11 & 4.6 \\
Unemployed & 15 & 6.3 \\
Others & 19 & 7.9 \\
Marital Status & & \\
Single & 188 & 78.3 \\
Married & 48 & 20 \\
Divorced & 1 & 0.4 \\
Cohabitating (unmarried) & 3 & 1.3 \\
Region & & \\
Sumatra & 14 & 5.8 \\
Java & 176 & 73.3 \\
Kalimantan & 25 & 10.4 \\
Sulawesi & 17 & 7.1 \\
Bali & 3 & 1.3 \\
NTB & 1 & 0.4 \\
Papua & 1 & 0.4 \\
Others & 3 & 1.3 \\
\hline
\end{tabular}

\section{Results of WHO ACE-IQ's validity and reliability}

In this current study, WHO ACE-IQ instrument evidenced strong internal consisteny ( $\alpha=$ 0.742). According to DeVaus (2004), the value indicates that WHO ACE-IQ is a reliable instrument. Then, the researcher tested the correlation between the total scores of WHO ACE-IQ and ACEQ questionnaires using Pearson's Product Moment. It was found that the two instruments are significantly correlated $(r=0.807, p<0.01)$. Further, the Pearson's Product Moment correlation was also performed on each subscale's score of WHO ACEIQ and ACEQ. The correlation results can be seen in Table 3.

Table 3.

The Correlation of WHO ACE-IQ and ACEQ's Subscales

\begin{tabular}{llc}
\hline No & \multicolumn{1}{c}{ Category } & Correlation of ACE-IQ and ACEQ \\
\hline 1 & Emotional neglect & $0.390^{* *}$ \\
2 & Physical neglect & $0.205^{* *}$ \\
3 & Alcohol and/or drug abuser in the household & $0.402^{* *}$ \\
4 & Family member who is chronically depressed, mentally ill, & $0.768^{* *}$ \\
& institutionalized or suicidal & \\
5 & Incarcerated family member & $0.724^{* *}$ \\
\hline
\end{tabular}




\begin{tabular}{llc}
\hline 6 & One of or both parents passed away, separated, or & $0.728^{* *}$ \\
7 & divorced & $0.395^{* *}$ \\
8 & Family member received abuse & $0.628^{* *}$ \\
9 & Psychological/emotional abuse & $0.640^{* *}$ \\
10 & Physical abuse & $0.525^{* *}$ \\
11 & Pexual abuse & - \\
12 & Community violence & - \\
13 & Collective violence & - \\
\hline
\end{tabular}
${ }^{* *} \mathrm{p}<0.05$

\section{Discussion}

This study became the first published article that adapted and validated WHO ACEIQ in Indonesia. It also supports the previously published papers about WHO ACE-IQ that has been used in several other countries such as Canada, Saudi Arabia, China, South Africa, Macedonia, Philippines, Switzerland, and Thailand (World Health Organization, 2018). This study evaluated and evaluated the validity and reliability of WHO ACE-IQ within the context of the Indonesian language and culture. The reliability estimate using Cronbach's alpha shows that WHO ACE-IQ is a reliable instrument to measure adverse childhood experiences of the adult population in Indonesia. This instrument can be used to conduct a descriptive study about ACE in Indonesia generally because it portrays all aspects and forms of adverse childhood experience in an instrument, WHO ACE-IQ. It is considered a comprehensive yet simple instrument and thus can be used as a national screening tool because previous national surveys of adverse experiences often overlook neglect and sexual abuse (Finkelhor \& Lannen, 2015). Additionally, it is a self-reporting instrument, and thus can protect participants' privacy and anonymity

This instrument can be used to conduct a descriptive study about ACE in Indonesia in general because it portrays all aspects and forms of adverse childhood experience within one measurement. The instrument is considered holistic yet simple so that it can be utilized as a national screening tool because the previous national adverse experience surveys tend to overlook necessary variables such as neglect and sexual abuse (Finkelhor \& Lannen, 2015). In addition, this instrument is in a self-reporting format, thus protecting study participants' privacy and anonymity so that data can represent the real situation. It is aligned with a suggestion by Rumble et al. (2018) about the data collection method regarding adverse experiences.

Compared with the ACEQ instrument developed by US Centers for Disease Control and Prevention and Kaiser Permanente in 1997, WHO ACE-IQ is superior because it focuses on all components in the construct of childhood trauma. Similar to WHO ACE-IQ, ACEQ itself is a self-report questionnaire that already has strong psychometric properties for clinical and non-clinical samples. This scale has also been widely used in various countries, while WHO ACE-IQ is a relatively new instrument that has started to be used 
in several countries (World Health Organization, 2018). Although nearly equal, there are several differences in measuring aspects between WHO ACE-IQ and ACEQ. WHO ACEIQ measures 13 subscales while ACEQ measures 10 subscales. The major difference between the two is WHO ACE-IQ includes additional forms of violence (peer violence/bullying, communal violence, and collective violence) which are not found in ACEQ. Researchers maintained the three violence categories in WHO ACE-IQ because they are deemed suitable for the Indonesian context. The trend of violence in Indonesia can be seen in bullying cases (Yulianti et al., 2020); community violence such as gang, klithih (Febriani, 2018; Sarmini et al., 2020), and others; as well as collective violence which happened in various conflict-affected areas including Aceh and Papua (Aslami, 2021) due to sensitive issues like ethnicities, religions, and such. Results from the analysis confirm that all items in WHO ACE-IQ are pivotal and provide an independent contribution towards the Indonesian context.

Follow-up studies about the main theme of adverse childhood experience in Indonesia, using WHO ACE-IQ, need to be done continuously in a larger population. This is important as the instrument still requires further evaluation to improve and polish its use. Future studies about adverse childhood experiences using WHO ACE-IQ can add information related to its reliability and validity. Additionally, Indonesia needs to catch up with the number of studies about this topic because it requires serious attention. According to the National Commission of Child Protection (in Paramastri \& Priyanto, 2015), violence towards children commonly occurs before 15 years old, around $80 \%$ of the cases, and the perpetrators are mostly known to the children. Considering the number of cases and the effects on the victim's life down the road, it should be the government and stakeholders' priority in Indonesia. Paramastri and Priyanto (2015) reported that early prevention to avoid abuse, particularly sexual abuse, in children is not commonly implemented in the programs from government, school, community, and even family. Early prevention such as psychoeducational activities to introduce what is abuse, sex education, identifying abuse perpetrators, and so on are important to prevent abuse in children (Paramastri \& Priyanto, 2015). The implementation of a psychoeducational program as early prevention for child sexual abuse can improve teacher's awareness and self-efficacy to participate in preventing and teaching prevention of abuse in children (Islawati \& Paramastri, 2015).

To promote programs and policies related to prevention and curation due to child abuse, there needs to be a database from varied and comprehensive studies about ACE in Indonesia. Unfortunately, at the moment, the prevalence of adverse childhood experiences among Indonesian people is not precisely known. The same case with studies that revealed the effect, risk factors, protective factors, and neural mechanism of childhood trauma; the number is limited and might be nonexistent. A fact from Rumble et al. (2020) through a systematic literature review by the United Nations Children's Fund showed the limited number of studies discussing sex abuse in children in Indonesia. This 
also applies to other abuse cases. Thus, the availability of valid and reliable screening instruments to measure childhood adverse experiences such as this WHO ACE-IQ is expected to be used as a comprehensive measurement for future studies.

\section{Conclusion}

This paper is the first publication reporting WHO ACE-IQ as a tool to measure childhood adverse experiences in Indonesia. The finding shows that WHO ACE-IQ is reliable and has validity proof therefore can be used to further study ACE in Indonesia, even on a national scale. By using a national standard measurement of ACE, researchers will obtain more comprehensive and valid results in studies about ACE, with varied topics.

\section{Suggestion}

Future studies that are broader and national-scale to understand all the aspects, factors, and impacts of ACE in Indonesia are needed, especially to accommodate situations in 34 different provinces. Furthermore, studies that investigate the effects of ACE on mental and physical health are required for the basis to develop a national policy regarding child protection, including a family affirmation program as a preventive step, as well as formulating a better clinical intervention for the victims of child abuse.

The limitation of this pilot study is the small sample size, non-proportionate representation of male and female samples, and non-random sampling method. Although the total number of participants was adequate for conducting validation of WHO ACE-IQ, it did not represent the population size of Indonesia, and thus the data obtained from this pilot study is not adequate to explain the prevalence of adverse childhood experiences in the country. This study would be relevant to portray the overall image of the child abuse trend across regions in Indonesia.

Future studies should consider the adverse experience in balanced male and female samples, coverage of all regions/provinces in Indonesia, as well as reaching out to conflict areas in the country. Thus, more comprehensive data could be obtained.

\section{Acknowledgment}

The study received a Research Grant from the Faculty of Psychology Universitas Gadjah Mada in 2019. The authors would like to thank the research participants and research assistants, Ahmad Ismi Maulana and Lovera Nadira, who had helped during the data collection process.

\section{Author's contribution}

SR designed the study and analyzed the data. VSP analyzed the data. SR, VSP, and AKP read, edited, and approved the final version of the manuscript. 


\section{Conflict of interest}

The authors declare no conflict of interest in the research, writing, and/or publication of this article.

\section{References}

Aslami, I. F. (2021). Kekerasan kolektif sebagai kejahatan: Suatu kajian kriminologi dan filsafat hukum. Res Justitia: Jurnal Ilmu Hukum, 1(1), 58-69. https://doi.org/10.46306/rj.v1i1

DeVaus, D. (2004). Surveys in Social Research (5th ed.). Routledge.

Dube, S. R., Anda, R. F., Whitfield, C. L., Brown, D. W., Felitti, V. J., Dong, M., \& Giles, W. H. (2005). Long-term consequences of childhood sexual abuse by gender of victim. American Journal of Preventive Medicine, 28(5), 430-438. https://doi.org/10.1016/j.amepre.2005.01.015

Dube, S. R., Felitti, V. J., Dong, M., Chapman, D. P., Giles, W. H., \& Anda, R. F. (2003). Childhood abuse, neglect, and household dysfunction and the risk of illicit drug use: The adverse childhood experiences study. Pediatrics, 111(3), 564-572. https://doi.org/10.1542/peds.111.3.564

Febriani, A. (2018). Klithih: Faktor risiko dan developmental pathway pelakunya. Humanitas, 15(2), 145. https://doi.org/10.26555/humanitas.v15i2.10536

Felitti, V. J., Anda, R. F., Nordenberg, D., Williamson, D. F., Spitz, A. M., Edwards, V., Koss, M. P., \& Marks, J. S. (1998). Relationship of childhood abuse and household dysfunction to many of the leading causes of death in adults. American Journal of Preventive Medicine, 14(4), 245-258. https://doi.org/https://doi.org/10.1016/S07493797(98)00017-8

Finkelhor, D., \& Lannen, P. (2015). Dilemmas for international mobilization around child abuse and neglect. Child Abuse and Neglect, 50, 1-8. https://doi.org/10.1016/j.chiabu.2014.06.012

Fulu, E., Warner, X., Miedema, S., Jewkes, R., Roselli, T., \& Lang, J. (2013). Why do some men use violence against women and how can we prevent it? Summary report of quantitative findings from the United Nations Multi-country Study on Men and Violence in Asia and the Pacific. In Onu Mujeres (Vols. 1-108).

Gee, D. G., \& Casey, B. J. (2015). Neurobiology of Stress The impact of developmental timing for stress and recovery. Neurobiology of Stress, 1, 184-194. https://doi.org/10.1016/j.ynstr.2015.02.001

Hasan, A., Hyson, M., \& Chang, M. C. (2013). Early Childhood Education and Development in Poor Villages of Indonesia. The World Bank.

Hughes, K., Lowey, H., Quigg, Z., \& Bellis, M. A. (2016). Relationships between adverse childhood experiences and adult mental well-being: Results from an English national household survey. BMC Public Health, 16(1), 1-11. https://doi.org/10.1186/s12889-016- 
2906-3

Islawati, I., \& Paramastri, I. (2015). Program "Jari Peri" sebagai pelindung anak dari kekerasan seksual. Jurnal Psikologi, 42(2), 115. https://doi.org/10.22146/jpsi.7167

Kaloeti, D. V. S., Rahmandani, A., Sakti, H., Salma, S., Suparno, S., \& Hanafi, S. (2019). Effect of childhood adversity experiences, psychological distress, and resilience on depressive symptoms among Indonesian university students. International Journal of Adolescence and Youth, 24(2), 177-184. https://doi.org/10.1080/02673843.2018.1485584

LAWSHE, C. H. (1975). A quantitative approach to content validity. Personnel Psychology, 28(4), 563-575. https://doi.org/10.1111/j.1744-6570.1975.tb01393.x

Lui, P. S. C., Dunne, M. P., Baker, P., \& Isom, V. (2018). Adverse childhood experiences, mental health, and risk behaviors among men in the Solomon Islands. Asia-Pacific Journal of Public Health, 30(6), 582-591. https://doi.org/10.1177/1010539518792911

Mersky, J. P., Topitzes, J., \& Reynolds, A. J. (2013). Impacts of adverse childhood experiences on health, mental health, and substance use in early adulthood: A cohort study of an urban, minority sample in the U.S. Child Abuse and Neglect, 37(11), 917925. https://doi.org/10.1016/j.chiabu.2013.07.011

Norman, R. E., Byambaa, M., De, R., Butchart, A., Scott, J., \& Vos, T. (2012). The LongTerm Health Consequences of Child Physical Abuse, Emotional Abuse, and Neglect: A Systematic Review and Meta-Analysis. PLoS Medicine, 9(11). https://doi.org/10.1371/journal.pmed.1001349

Paramastri, I., \& Priyanto, M. A. (2015). Early Prevention Toward Sexual Abuse on Children. Jurnal Psikologi, 37(1), 1 - 12-12. https://doi.org/10.22146/jpsi.7688

Pebruarini, V., Elnadus, N., \& Sumampouw, J. (n.d.). The Relationship between Adverse Childhood Experience and the Tendency of Malingering on Adult Inmates at Salemba, Cipinang, and Cibinong Prison.

Ramiro, L. S., Madrid, B. J., \& Brown, D. W. (2010). Adverse childhood experiences (ACE) and health-risk behaviors among adults in a developing country setting. Child Abuse and Neglect, 34(11), 842-855. https://doi.org/10.1016/j.chiabu.2010.02.012

Rumble, L., Febrianto, R. F., Larasati, M. N., Hamilton, C., Mathews, B., \& Dunne, M. P. (2020). Childhood sexual violence in Indonesia: A systematic review. Trauma, Violence, and Abuse, 21(2), 284-299. https://doi.org/10.1177/1524838018767932

Rumble, L., Ramly, A. A., Nuryana, M., \& Dunne, M. P. (2018). The importance of contextual factors in carrying out childhood violence surveys: A case study from Indonesia. Child Indicators Research, 11(2), 405-421. https://doi.org/10.1007/s12187-0179457-8

Sarmini, M., Kurniyatuti, N., \& Sukartiningsih, S. (2020). Klithih: Invisible crime by teenagers. 226(Icss), 1578-1582. https://doi.org/10.2991/icss-18.2018.328

Thang, N. H., Anh, L. V., Peltzer, K., Pengpid, S., Low, W. Y., \& Win, H. H. (2017). Childhood emotional, physical, and sexual abuse and associations with mental health and health-risk behaviors among university students in the Association of 
Southeast Asian Nations (ASEAN). Child Studies in Asia-Pacific Contexts, 7(1), 15-26. https://doi.org/10.5723/csac.2017.7.1.015

Van der Kolk, B. (2015). The body keeps the score: Brain, mind, and body in the healing of trauma. Penguin Books.

World Health Organization. (2018). Adverse Childhood Experiences International Questionnaire.

https://www.who.int/violence_injury_prevention/violence/activities/adverse_childho od_experiences/en/

Yulianti, K. Y., Wijayanti, Y., \& Ramdhani, N. (2020). Konseling Daring Pendukung Siswa Cerdas (KDPSC): A preliminary evaluation of iCBT treatments for Indonesian Freshmen with social anxiety. Gadjah Mada Journal of Professional Psychology (GamaJPP), 6(1), 1. https://doi.org/10.22146/gamajpp.54888 